\title{
Perlindungan Hukum Bagi Nasabah dan Tanggung Jawab Bank Dalam Kasus Card Skimming
}

\author{
Reza Aditya Pamuji \\ rezabachtiar2005@gmail.com
}

\begin{abstract}
This study aimed to examine the legal protection and accountability of banks towards the security of customers' personal data and deposit in a card skimming case. The research used the normativeempirical approach to related laws and regulations, which were then correlated with the practical implementation. Through a descriptive analysis, this study explained the existing regulations associated with legal theories in practice. Data collection was conducted through library research and interviews. The results indicated that banks are responsible for losses suffered by customers due to card skimming thefts provided that it is proven with CCTV camera recordings and there is no element of negligence from the customer as a victim. Legal protection for customers relating to the accountability of banks should be based on Law No. 8 of 1999 on Consumer Protection, Bank Indonesia Regulation No. 16/1/PBI/2014 concerning Consumer Protection of Payment System Services, and Regulation of Financial Services Authority No. 1/POJK.07/2013 regarding Consumer Protection of Financial Services Sector.
\end{abstract}

Keywords: Banking; ATM cards; ATM machine; card skimming

\begin{abstract}
Abstrak
Penulisan ini bertujuan untuk mengetahui perlindungan hukum serta pertanggungjawaban pihak bank terhadap keamanan data pribadi nasabah maupun dana simpanan nasabah yang ada pada bank dalam kasus card skimming. Penelitian ini menggunakan pendekatan normatif-empiris yaitu pendekatan undang-undang dan regulasi yang bersangkut paut lalu dikaitkan dengan penerapannya yang terjadi di lapangan. Penelitian ini bersifat deskriptif analisis yang mana menggambarkan peraturan-peraturan yang berlaku dikaitkan dengan teori-teori hukum dalam praktek pelaksanaannya. Pengumpulan data dilakukan dengan cara library research dan wawancara. Hasil penelitian ini menunjukkan bahwa bank bertanggungjawab terhadap kerugian yang dialami nasabah atas pencurian dengan modus card skimming, dengan catatan harus dibuktikan dengan rekaman kamera cctv dan tidak ada unsur kelalaian dari pihak nasabah yang menjadi korban. Perlindungan hukum kepada nasabah berkaitan dengan pertanggungjawaban yang diberikan pihak bank yaitu berdasarkan Undang-Undang No. 8 Tahun 1999 tentang Perlindungan Konsumen, PBI No. 16/1/PBI/2014 tentang Perlindungan Konsumen Jasa Sistem Pembayaran dan POJK No. 1/POJK.07/2013 tentang Perlindungan Konsumen Sektor Jasa Keuangan.
\end{abstract}

Kata-kata Kunci: Perbankan; kartu ATM; mesin ATM; card skimming 


\section{Pendahuluan}

Bank sebagai lembaga utama di bidang keuangan diharapkan dapat menjaga kepercayaan masyarakat atas simpanan yang ditanamkan kepadanya. Mengingat tugas tersebut memiliki sifat yang berbeda antara yang satu dengan yang lainnya, pengaturan atas industri perbankan nasional mutlak diperlukan untuk menjaga keseimbangan di antara tugas-tugas di atas. Dalam hal ini peranan Bank Indonesia dan Otoritas Jasa Keuangan sebagai otoritas perbankan nasional di tanah air menjadi sangat strategis. Oleh karena itu, menurut Shelagh Heffernan, bahwa bank adalah salah satu pemangku regulasi tertinggi karena kegagalan bank akan menimbulkan biaya sosial yang tinggi berupa hilangnya peran bank sebagai lembaga intermediasi dan transmisi dalam sistem pembayaran. ${ }^{1}$

Saat ini sebagian besar perbankan telah mengeluarkan produk kartu plastik sebagai upaya memberikan kepuasan kepada nasabah. Kartu ATM (Anjungan Tunai Mandiri), biasanya diberikan kepada setiap nasabah yang ingin memiliki kartu untuk kemudahan dalam melakukan transaksi keuangan. Beberapa bank juga memberikan fasilitas kartu debit pada kartu ATM yang dapat digunakan untuk transaksi pembelian barang. Pada dasarnya kartu plastik bertujuan untuk mengurangi penggunaan uang tunai dalam melakukan berbagai transaksi keuangan. Hal ini dilakukan dengan alasan kemudahan serta keamanan. ${ }^{2}$

Fasilitas bank berupa ATM merupakan sarana teknologi yang dapat melayani kebutuhan nasabah secara otomatis setiap saat (24 jam) dan 7 hari dalam seminggu termasuk hari libur, ${ }^{3}$ namun dibalik kemudahan dan keamanan teknologi mesin ATM ternyata masih terdapat kelemahan. Kenyataan yang terjadi di lapangan, masyarakat dikejutkan dengan hilangnya sejumlah dana nasabah melalui mesin ATM tanpa diketahui siapa dan kapan transaksi tersebut dilakukan sedangkan nasabah pemilik kartu tidak merasa melakukan transaksi yang dimaksud.

Nasabah sebagai konsumen wajib mendapat perlindungan hukum atas pemanfaatan produk jasa yang ditawarkan oleh bank. Perlindungan hukum

\footnotetext{
${ }^{1}$ Shelagh Heffernan dikutip dari Jonker Sihombing, Penjaminan Simpanan Nasabab Perbankan, PT. Alumni, Bandung, 2010, hlm. 2

${ }^{2}$ Ade Arthesa \& Edia Handiman, Bank \& Lembaga Keuangan Bukan Bank, PT. Indeks, Jakarta, 2006, hlm. 258-259.

${ }^{3}$ Kasmir, Dasar-Dasar Perbankan, PT. RajaGrafindo Persada, Jakarta, 2008, hlm. 182.
} 
merupakan suatu upaya dalam mempertahankan serta memelihara kepercayaan masyarakat luas khususnya nasabah. ${ }^{4}$ Permasalahan hilangnya dana nasabah tersebut merupakan akibat kurangnya perlindungan bank terhadap para nasabahnya.

Kerugian dapat terjadi baik pada pelaku transaksi maupun pada orang lain yang tidak pernah melakukan transaksi, misalnya dalam hal ini pencurian dana nasabah bank melalui modus skimmer (penggandaan kartu Anjungan Tunai Mandiri/ATM). Pencurian dana nasabah bank melalui modus penggandaan kartu ATM merupakan salah satu kejahatan teknologi di bidang perbankan. Beberapa waktu lalu, modus pencurian dana nasabah bank melalui penggandaan kartu ATM semakin meningkat. Hal ini sebetulnya telah lama diketahui bersama dan telah banyak kasus yang terjadi. Kejadian pun terulang kembali sampai berita tentang pencurian dana 200 nasabah BCA melalui ATM, diketahui oleh masyarakat. 5

Salah satu korban bernama Grace Simon yang merupakan seorang penyanyi populer pada 1970-an, telah melapor kepada pihak kepolisian sebagai salah satu korban pembobolan ATM. Grace kehilangan Rp. 20.000.000,00 dari rekeningnya di Bank BCA. Akan tetapi, pihak bank BCA telah mengganti kerugian yang dialaminya. ${ }^{6}$

Kasus lain terjadi pada seorang nasabah Bank Mandiri bernama Surianty yang merasa telah kehilangan dana sebesar Rp. 19.450.000,00 pada rekeningnya, padahal si nasabah merasa tidak melakukan transaksi penarikan dari tabungan. Kemudian si nasabah mencari tahu penyebab raibnya uang simpanannya. Ternyata memang benar telah terjadi transaki dengan menggunakan kartu ATM.7

Masalahnya, respon bank cukup sederhana, bank menganggap tidak ada masalah sama sekali pada proses transaksi dan memosisikan pengadu untuk bertanggung jawab sendiri atas masalah itu. Menurut bank semua proses transaksi sah dan tidak ada yang mencurigakan. ${ }^{8}$

\footnotetext{
${ }^{4}$ Hermansyah, Hukum Perbankan Nasional Indonesia. edisi ke-2. Jakarta: Kencana, 2013, hlm 146.

5http://bisniskeuangan.kompas.com/read/2010/01/22/07010927/Bank.Harus.Bayar.Nasabah diakses pada tanggal 1 Juni 2016 pukul 20.00 WIB

${ }^{6}$ Ibid

7 Ronny Prasetya, Pembobolan ATM; Tinjauan Hukum Perlindungan Nasabah Korban Kejahatan Perbankan, Prestasi Pustaka Publisher, Jakarta, 2010, hlm. 55

8 Ibid., hlm. 56
} 
Merujuk pada Pasal 37 B angka 1 Undang-Undang Nomor 10 Tahun 1998 tentang Perbankan yang telah Diubah menyebutkan, "setiap bank wajib menjamin dana masyarakat yang disimpan pada bank yang bersangkutan". Kasus di atas menunjukkan masih terdapat kelemahan pada penerapan tanggung jawab bank kepada nasabah.

Berbagai kejahatan yang terjadi dengan menggunakan fasilitas perkembangan teknologi khususnya pencurian dana nasabah bank bermacammacam bentuknya, salah satunya dengan menggunakan modus penggandaan kartu ATM. Oleh karena itu, Penulis tertarik untuk melakukan penelitian pencurian dengan modus penggandaan kartu ATM tersebut.

\section{Rumusan Masalah}

Adapun dari uraian yang telah dikemukakan di atas, dapat ditarik rumusan masalahnya adalah: pertama, bagaimana tanggung jawab bank terhadap kerugian yang diderita nasabah dikarenakan adanya pencurian dana simpanannya dengan modus card skimming pada saat melakukan transaksi di ATM ? Kedua, bagaimana perlindungan hukum bagi nasabah yang mengalami kerugian atas modus card skimming pada saat melakukan transaksi di ATM?

\section{Tujuan Penelitian}

Atas dasar permasalahan yang telah dikemukakan di atas, tujuan yang hendak dicapai dari penelitian ini adalah: pertama, untuk mengetahui perlindungan hukum dalam sistem hukum di Indonesia yang dapat diberikan kepada nasabah bank pengguna ATM. Kedua, untuk mengetahui pertanggungjawaban yang dapat diberikan oleh pihak Bank berkenaan dengan kerugian yang diderita nasabah bank pengguna ATM dalam melakukan transaksi yang dikarenakan modus kejahatan skimmer.

\section{Metode Penelitian}

Dalam pembuatan jurnal ini, penulis menggunakan metode penelitian secara Yuridis Empiris yaitu melakukan pengkajian pelaksanaan ketentuan peraturan perundang-undangan secara faktual pada peristiwa hukum tertentu yang terjadi 
dalam masyarakat. ${ }^{9}$ Penelitian ini bersifat Deskriftif yaitu mendeskripsikan dan atau menggambarkan pelaksanaan suatu peraturan perundang-undangan untuk memecahkan permasalahan. ${ }^{10}$

Kemudian dijelaskan langkah-langkah pihak bank apabila menerima komplain atau laporan dari nasabahnya mengenai masalah kehilangan dana pada rekening akibat penggunaan kartu ATM. Setelah itu dijelaskan tindak lanjut pihak bank berkaitan dengan pengembalian dana nasabah apabila dari hasil pemeriksaan ternyata dana nasabah yang hilang bukan karena kesalahannya melainkan karena kejahatan penggandaan kartu ATM.

Data Primer yang dipakai dalam penelitian ini adalah data yang bersumber dari penelitian lapangan yaitu di Bank Indonesia Cabang Banjarmasin, Otoritas Jasa Keuangan Cabang D.I. Yogyakarta, Bank Mandiri Cabang Banjarmasin. Sedangkan data sekunder yang dipakai dalam penelitian ini adalah data yang bersumber dari data-data berupa dokumen yang sudah ada dalam bentuk bahan hukum.

\section{Hasil Penelitian dan Pembahasan}

\section{Teknik Pencurian Dana Simpanan Nasabah Melalui Mesin ATM dengan Modus Card Skimming}

Bank adalah suatu badan usaha yang berbadan hukum yang bergerak di bidang jasa keuangan. Bank sebagai badan hukum berarti secara yuridis adalah merupakan subyek hukum yang berarti dapat mengikatkan diri dengan pihak ketiga. ${ }^{11}$

Sesuai dengan perkembangan zaman, dewasa ini kegiatan menabung sudah beralih dari rumah ke lembaga keuangan seperti bank. Untuk menarik dana yang ada di rekening tabungan dapat digunakan berbagai sarana atau alat penarikan. Dalam praktiknya ada beberapa alat penarikan yang dapat digunakan, hal ini tergantung bank masing-masing. Salah satu alat penarikan yang digunakan untuk menarik dana yaitu berupa kartu yang terbuat dari plastik. Kartu ATM merupakan kartu plastik yang dilengkapi dengan magnetic stripe pada magnetic stripe akan

\footnotetext{
9 Abdul Kadir Muhammad, Hukum dan Penelitian Hukum, P'T.Citra Aditya Bakti, Bandung, 2004, hlm. 53

10 Soerjono Soekanto, Pengantar Penelitian Hukum, UI-Press, Jakarta, 1982, hlm. 50

${ }^{11}$ Sentosa Sembiring, Hukum Perbankan, CV. Mandar Maju, Bandung, 2000, hlm. 2
} 
terekam secara elektronik nomor kartu ATM, nama pemilik kartu, dan informasiinformasi lainnya yang diperlukan oleh sistem komputer. ${ }^{12}$

Sesuai Peraturan Bank Indonesia Nomor 11/11/PBI/2009, kartu ATM diartikan sebagai APMK yang dapat digunakan untuk melakukan penarikan tunai dan/atau pemindahan dana, yakni kewajiban pemegang kartu dipenuhi seketika dengan mengurangi secara langsung simpanan pemegang kartu pada bank atau lembaga selain bank (LSB) yang berwenang menghimpun dana sesuai ketentuan perundang-undangan yang berlaku. ${ }^{13}$

Di samping segi-segi positif tersebut, pengguna ATM juga tidak lepas dari kekurangan atau dampak yang sifatnya negatif. Kekurangan tersebut misalnya adanya kemungkinan kejahatan yang dilakukan oleh pihak ketiga dalam transaksi melalui ATM, yaitu dengan penggunaan langsung kartu ATM nasabah yang telah diketahui nomor PIN (Personal Identification Number)-nya, pemalsuan kartu, atau pencurian data nasabah pengguna ATM.

Terkait pencurian dana nasabah melalui mesin ATM dengan modus card skimming, pihak Bank Mandiri Lambung Mangkurat Cabang Banjarmasin menyebutkan terdapat berbagai macam teknik pencurian dana simpanan nasabah melalui mesin $\mathrm{ATM}^{14}$ Adapun cara pertama yaitu dengan melakukan penggandaan kartu ATM. Proses diawali dengan pemasangan skimmer dan kamera di mesin ATM yang tersebar di beberapa wilayah. Skimmer dipasang dengan menggunakan double tape pada mulut slot kartu ATM. Tujuan pemasangan skimmer ini adalah untuk merekam dan menjgambil data kartu ATM yang tertera pada pita magnetic stripe yaitu permukaan berwarna hitam pada kartu ATM. Sedangkan kamera sengaja dipasangi pelindung berwarna sesuai dengan mesin ATM agar tidak dapat terlihat, kemudian dipasang di atas keypad agar dapat melihat nomor PIN yang ditekan oleh nasabah. Pemasangan skimmer dan kamera tersebut

12 Dyah Worosari. Tinjauan Yuridis Terhadap Keamanan Penggunaan Kartu ATM/Debet di PT Bank. Negara Indonesia, Tbk (Persero). Skripsi: Universitas Indonesia, tidak diterbitkan, 2012, Hal. 16-17

${ }^{13}$ R. Serfianto, et. al, Untung dengan Kartu Kredit, Kartu ATM-Debit, dan uang Elektronik, Visimedia, Jakarta, 2012, hlm 18

${ }^{14}$ Wawancara dengan Pambudi, IT Infrastucture, Bank Mandiri Lambung Mangkurat cabang Banjarmasin, di Banjarmasin, 11 Januari 2017 
dipasang sekitar lima sampai dengan tujuh jam selanjutnya dilepas dan diambil datanya.

Setelah data kartu ATM milik nasabah yang sudah terekam di skimmer diambil, kemudian data dikirimkan kepada salah satu sindikat pelaku yang berada di luar negeri yaitu Bulgaria untuk dilakukan pengolahan data dengan cara menyesuaikan antara data yang terekam di skimmer dengan data nomor PIN yang terekam pada kamera tersembunyi. Pengolahan data tersebut dilakukan dengan waktu selama sekitar tiga bulan. Setelah pengolahan data selesai, hasilnya dikirimkan lagi kepada sindikat pelaku ke Indonesia.

Dari data yang sudah diterima tersebut, kemudian dibaca menggunakan alat bernama Magnetic Card Reader (MCR) yaitu alat pembaca data kartu magnetik yang sudah dihubungkan dengan komputer. Data masing-masing nasabah yang sudah ditata kemudiansatu persatu dibuatkan duplikat kartu ATM dengan cara digesek / swipe pada alat MCR sehingga secara otomatis data langsung masuk ke dalam kartu ATM tersebut. Selanjutnya kartu ATM dimasukkan ke dalam amplop dan di amplop ditulis nomor PIN masing-masing kartu ATM untuk memudahkan penggunaannya.

Setelah proses duplikasi kartu ATM tersebut selesai, kemudian semua kartu ATM yang sudah jadi dibagikan kepada beberapa anggota sindikat, masing-masing membawa dua puluh sampai dengan tiga puluh kartu ATM. Selanjutnya para pelaku melakukan pengambilan dana di mesin-mesin ATM dengan menggunakan semua kartu ATM duplikat tersebut. Setelah semua kartu dilakukan penarikan, para pelaku berkumpul kembali untuk mengumpulkan uang hasil penarikan kartu selanjutnya uang hasil kejahatan tersebut dibagikan kepada semua pelaku.

Yang kedua mengganti card reader, tetapi cara ini sudah tergolong kuno dan untuk mengganti card reader, si pelaku harus membuka ATMnya. Pada mesin ATM terdapat fascia (bukaan pintu) atas yang terdiri dari CPU, AC box, Card Reader, Receipt Printer, EPP, Softkey, Monitor dan faskia (bukaan pintu) bawah yang berisi uang.

Cara ketiga, yaitu dengan menambahkan alat perekam pada EDC, dan menggunakan tusuk gigi, tusuk gigi tersebut dimasukkan kedalam lubang tempat memasukkan kartu. Jadi, apabila si nasabah pertama kali memasukkan kartu ATM 
ke dalam mesin, akan mengalami kesulitan karena terganjal tusuk gigi tadi, setelah dipaksa masuk barulah kartu ATM tersebut bisa dimasukkan ke dalam mesin ATM, akan tetapi kartu ATM yang telah dimasukkan akan terjebak di dalam card reader, karena terganjal oleh tusuk gigi yang telah dipasang oleh pelaku sebagai perangkap kartu ATM yang dimasukkan nasabah. Secara spontan nasabah yang kartu ATM nya telah terjebak pada card reader tadi menjadi panik dan bingung, disaat itulah si pelaku mendatangi korban dengan berpura-pura untuk menolong. Setelah si pelaku berpura-pura memeriksa mesin ATM, ditukarlah kartu ATM nasabah yang asli dengan yang palsu, lalu si pelaku menyerahkan kartu ATM yang palsu tersebut kepada nasabah.

Di sini letak kelalaian nasabah, terkadang nasabah panik dan disitulah kesempatan bagi si pelaku untuk memainkan emosi korbannya. Otomatis si korban menjadi tidak fokus terhadap kartu ATM nya, dan langsung menerima apa saja yang diserahkan oleh si pelaku. Lalu si pelaku membawa alat perekam yang telah ditambahkan pada EDC tadi beserta kartu yang sudah terjebak di dalamnya, tetapi dengan catatan si pelaku juga telah menambahkan spy cam pada mesin ATM untuk merekam nomor PIN yang ditekan oleh si nasabah yang menjadi korban. Jadi ketika pelaku berpura-pura menolong korban, pelaku menyuruh korban untuk mencoba memasukkan PIN agar terlihat bahwa mesin ATM bekerja dengan wajar, pada saat itulah, spy cam tersebut merekam tombol angka yang ditekan oleh korban pada mesin ATM.

\section{Tanggung Jawab Bank Terhadap Nasabah Yang Mengalami Kerugian atas pencurian dana simpanannya melalui mesin ATM dengan Modus Card Skimming}

Menurut Fadhil Hasan selaku pengamat perbankan, tindakan bank memberikan penggantian terhadap nasabah yang menjadi korban pembobolan ATM memang bagus karena membebaskan korban dari risiko kehilangan dana. Tapi tindakan itu saja tidak cukup bisa meredakan keresahan masyarakat menyangkut keamanan dana mereka di perbankan nasional. Selama aparat berwenang tidak mampu untuk segera mengungkap kasus-kasus pembobolan yang sudah terjadi, dan di sisi lain pengelola perbankan tidak bisa meyakinkan masyarakat menyangkut sistem pengamanan dana nasabah, keresahan masyarakat 
bisa tetap semakin menjadi-jadi dan meluas. Apabila sudah terjadi demikian, perbankan nasional harus menanggung risiko dampak sistemik kasus pembobolan ATM.15

Menurut Abdul Kadir Muhammad, teori tanggung jawab dalam perbuatan melanggar hukum dibagi menjadi beberapa teori, yaitu: ${ }^{16}$ pertama, tanggung jawab akibat perbuatan melanggar hukum yang dilakukan dengan sengaja, tergugat harus sudah melakukan perbuatan sedemikian rupa sehingga merugikan penggugat atau mengetahui bahwa apa yang dilakukan tergugat akan mengakibatkan kerugian. Kedua, tanggung jawab akibat kerugian perbuatan melanggar hukum yang dilakukan karena kelalaian, didasarkan pada konsep kesalahan yang berkaitan dengan moral dan hukum yang sudah bercampur baur. Ketiga, tanggung jawab mutlak akibat perbuatan melanggar hukum tanpa mempersoalkan kesalahan, didasarkan pada perbuatannya baik secara sengaja maupun tidak sengaja, artinya meskipun bukan kesalahannya tetap bertanggung jawab atas kerugian yang timbul akibat perbuatannya.

Adapun peneliti melakukan wawancara terhadap salah satu bank di Banjarmasin terkait penerapannya dalam melakukan tanggung jawab terhadap nasabah yang mengalami kerugian atas hilangnya dana simpanan yang diduga melalui mesin ATM. Pambudi mengatakan Modus pembobolan ATM dengan card skimming biasanya menggunakan kamera kecil. Beliau mengharapkan agar nasabah, khususnya Bank Mandiri, untuk tidak perlu khawatir. Sebab, Bank Mandiri telah menerapkan IT Security yang kuat dan menerapkan anti-skimming.17

Lebih jauh beliau menuturkan, dengan anti-skimming, ATM Bank Mandiri tidak memiliki celah untuk ditembus dengan micro camera itu, jadi dapat dikatakan bahwa ATM bank Mandiri untuk sementara masih aman. “Untuk saat ini memang, kartu ATM nasabah Bank Mandiri belum dipasang chip. Namun, tanpa itupun ATM sudah cukup aman. Jika ternyata ada nasabah yang mengalami pembobolan

\footnotetext{
${ }^{15}$ Fadhil Hasan, dikutip dari Ronny Prasetya, Pembobolan ATM, Tinjauan Hukum Perlindungan Nasabab Korban Kejahatan Perbankan, PT. PrestasiPustakaraya, Jakarta, 2010, hlm. 40

${ }^{16}$ Abdul Kadir Muhammad, Hukum Perusahaan Indonesia, Citra Aditya Bakti, Bandung, 2010, hlm. 503

17 Wawancara dengan Pambudi, IT Infrastructure, Bank Mandiri Lambung Mangkurat cabang Banjarmasin, di Banjarmasin, 11 Januari 2017
} 
saldo yang diduga melalui mesin ATM, bisa langsung melaporkannya ke call center 14000 atau datang langsung ke kantor cabang terdekat. Pihak bank akan melakukan verifikasi, apabila memang nasabah tidak melakukan transaksi, tetapi saldo yang dimilikinya berkurang, dan memang terbukti benar bukan nasabah yang bersangkutan yang melakukan transaksi dengan dibuktikan melalui rekaman CCTV maka saldo yang hilang akan diganti. Dengan cara, nasabah cukup membawa kartu ATM dan buku tabungannya". ${ }^{18}$

Apabila terdapat unsur kelalaian pada nasabah dalam menjaga kerahasiaan PIN, misalnya ketika nasabah melakukan transaksi pada mesin ATM, tetapi dia tidak berusaha menutupi keyboard yang dia tekan, dan ketika dia menekan tombol dapat membuat orang yang sedang mengantri di belakang bisa melihat, dan terbukti dengan adanya rekaman cctv, maka hal seperti itu pihak bank tidak akan memberikan ganti rugi apabila terjadi pencurian saldo rekening yang dimiliki oleh nasabah tersebut, jadi semua tergantung bagaimana nasabah menjaga kerahasiaan PIN nya. Akan tetapi apabila nasabah sudah berusaha untuk menutupi keyboard pada mesin ATM ketika melakukan transaksi, namun ternyata ada alat lain yang dipasangi pada mesin ATM tersebut dan itu di luar kemampuan nasabah dalam mengurangi resiko kebocoran PIN ATM yang dia miliki dan secara prosedur dia tidak melakukan kesalahan, dia sudah berusaha menutupi keyboard, dan terbukti dengan rekaman cctv, maka bank akan bertanggung jawab dengan memberikan ganti rugi.

\section{Perlindungan Hukum Terhadap Nasabah Bank yang Mengalami Kerugian Finansial atas pembobolan ATM melalui teknik Card Skimming}

Pada dasarnya tidak semua pengaduan nasabah yang melaporkan kehilangan uang dalam rekeningnya mendapatkan pengembalian dari pihak bank. Pihak bank akan melakukan klarifikasi terlebih dahulu terhadap pengaduan nasabah tersebut, apakah pengaduan nasabah itu memang kehilangan uang dalam rekeningnya karena kejahatan penggandaan kartu ATM atau uang nasabah tersebut hilang karena sebab lain terutama disebabkan karena kelalaian nasabah. 
Perlidungan hukum terhadap nasabah dapat dilakukan dalam 2 cara yaitu :19 pertama, perlindungan tidak langsung, yaitu perlindungan hukum yang diberikan kepada nasabah terhadap semua resiko kerugian yang mungkin timbul akibat suatu kebijaksanaan atau kegiatan usaha bank. Kedua, perlindungan langsung, yaitu perlindungan secara langsung terhadap nasabah terhadap kemungkinan resiko kerugian yang timbul dari kegiatan usaha yang dilakukan oleh bank.

Nasabah sebagai konsumen menurut ketentuan Pasal 19 ayat (3) dan Pasal 45 ayat (1) dan Pasal 47 Undang-Undang Nomor 8 Tahun 1999 tentang perlindungan konsumen menyebutkan sengketa konsumen dapat diselesaikan di luar pengadilan dan melalui pengadilan. Setiap konsumen yang dirugikan dapat menggugat pelaku usaha melalui lembaga yang bertugas menyelesaikan sengketa antara konsumen dan pelaku usaha atau melalui peradilan umum (UUPK Pasal 45 ayat (1)) ataupun penyelesaian sengketa konsumen dapat ditempuh melalui pengadilan atau diluar pengadilan berdasarkan dengan pilihan sukarela para pihak yang bersengketa (UUPK Pasal 45 ayat (2)).

Menurut UUPK Pasal 48 penyelesaian sengketa konsumen yang dilakukan melalui jalur Pengadilan Negeri (PN) adalah penyelesaian sengketa yang mengacu pada ketentuan peradilan umum yang berlaku. Penyelesaian sengketa melalui pengadilan dapat dilakukan oleh konsumen yang telah dirugikan atau ahli waris yang bersangkutan, sekelompok konsumen yang mempunyai kepentingan yang sama, pemerintah dan/atau instansi terkait ataupun lembaga perlindungan konsumen swadaya masyarakat (LPKSM).

Menurut Pasal 19 ayat (1) dan (3) Undang-Undang Perlindungan Konsumen, konsumen yang merasa dirugikan dapat menuntut secara langsung penggantian kerugian kepada produsen dan produsen harus memberi tanggapan dan/atau penyelesaian dalam jangka waktu 7 hari setelah transaksi berlangsung. ${ }^{20}$ Selain itu, penyelesaian sengketa konsumen juga tidak menutup kemungkinan penyelesaian secara damai oleh pihak yang bersengketa.

${ }^{19}$ Hermansyah, Hukum Perbankan Indonesia, Edisi Revisi, Kencana, Jakarta, 2009, hlm. 154 $130-131$

${ }^{20}$ Janus Sidabalok, Hukum Perlindungan Konsumen di Indonesia, PT.Citra Aditya Bakti, Bandung, 2006, hlm. 
Adapun Otoritas Jasa Keuangan mempunyai tugas untuk memberikan perlindungan hukum kepada konsumen lembaga jasa keuangan. Terkait kasus card skimming yang mengakibatkan kerugian bagi nasabah bank, Undang-Undang Otoritas Jasa Keuangan mengatur mengenai perlindungan konsumen dan masyarakat dengan melakukan tindakan pencegahan kerugian konsumen dan masyarakat, yang meliputi:21

1. Memberikan informasi dan edukasi kepada masyarakat atas karakteristik sektor jasa keuangan, layanan, dan produknya;

2. Meminta lembaga jasa keuangan untuk menghentikan kegiatannya apabila kegiatan tersebut berpotensi merugikan masyarakat; dan

3. Tindakan lain yang dianggap perlu sesuai dengan ketentuan peraturan perundang-undangan di sektor jasa keuangan.

"Kami selaku Otoritas Jasa Keuangan dalam memberikan perlindungan terhadap nasabah yang mengalami kerugian berdasarkan pada Undang-Undang Otoritas Jasa Keuangan", terang Diantika selaku pihak OJK.22

Di samping upaya pencegahan pelanggaran ketentuan dalam Undangundang Otoritas Jasa Keuangan, terdapat beberapa instrumen untuk pelayanan pengaduan konsumen atas pelanggaran yang dilakukan oleh pelaku usaha, yang meliputi:23

1. Menyiapkan perangkat yang memadai untuk pelayanan pengaduan konsumen yang dirugikan oleh pelaku di lembaga jasa keuangan;

2. Membuat mekanisme pengaduan konsumen yang dirugikan oleh pelaku di lembaga jasa keuangan; dan

3. Memfasilitasi penyelesaian pengaduan konsumen yang dirugikan oleh pelaku di lembaga jasa keuangan sesuai dengan peraturan perundangundangan di sektor jasa keuangan.

Otoritas Jasa Keuangan memuiliki 2 (dua) kewenangan dalam pembelaan hukum bagi konsumen, yaitu: ${ }^{24}$

1. Memerintahkan atau melakukan tindakan tertentu kepada pelaku usaha sektor jasa keuangan untuk menyelesaikan pengaduan konsumen yang dirugikan oleh pelaku usaha sektor jasa keuangan dimaksud;

2. Mengajukan gugatan:

${ }^{21}$ Pasal 28 Undang-Undang Otoritas Jasa Keuangan

${ }^{22}$ Wawancara dengan Asteria Diantika, Departemen Edukasi dan Perlindungan Konsumen, Otoritas Jasa Keuangan Kantor Regional D.I. Yogyakarta, di Yogyakarta, 5 Januari 2017

${ }^{23}$ Pasal 29 Undang-Undang Otoritas Jasa Keuangan

${ }^{24}$ Pasal 30 Undang-Undang Otoritas Jasa Keuangan 
a. Untuk memperoleh kembali harta kekayaan milik pihak yang dirugikan dari pihak yang menyebabkan kerugian, baik yang berada di bawah penguasaan pihak yang menyebabkan kerugian dimaksud maupun dibawah penguasaan pihak lain dengan itikad baik; dan/atau

b. Untuk memperoleh ganti kerugian dari pihak yang menyebabkan kerugian pada konsumen dan/atau lembaga jasa keuangan sebagai akibat dari pelanggaran atas peraturan perundang-undangan di sektor jasa keuangan.

Pada 2013 sebagai salah satu bentuk kewenangannya, Otoritas Jasa Keuangan menerbitkan Peraturan Otoritas Jasa Keuangan No. 1/POJK.07/2013 tentang Perlindungan Konsumen Sektor Jasa Keuangan. Prinsip perlindungan yang dimuat dalam peraturan tersebut yaitu transparansi, perlakuan adil, keandalan, kerahasiaan dan keamanan data/informasi konsumen, dan penanganan pengaduan serta penyelesaian sengketa konsumen secara sederhana, cepat dan biaya ringan. ${ }^{25}$

Adapun pihak Bank Indonesia menjelaskan, perlindungan hukum terhadap nasabah yang mengalami kerugian dapat dilihat melalui Peraturan Bank Indonesia Nomor 16/1/PBI/2014 tentang Perlindungan Konsumen Jasa Sistem Pembayaran. Perlindungan Konsumen Jasa Sistem Pembayaran yang selanjutnya disebut Perlindungan Konsumen adalah segala upaya yang menjamin adanya kepastian hukum untuk memberi perlindungan kepada Konsumen Jasa Sistem Pembayaran.

Namun Bank Indonesia menegaskan tidak ada judgement terhadap bank tertentu untuk memberikan ganti rugi kepada nasabah yg mengalami kerugian terkait pembobolan dana nasabah melalui mesin ATM dengan modus card skimming, tetapi hanya memberikan fasilitas berupa mediasi antara pihak nasabah yang mengalami kerugian dengan bank yang menyimpan dana nasabah tersebut. ${ }^{26}$

Terhadap kerugian yang dialami nasabah, Bank Indonesia telah menghimbau bank untuk tetap memperhatikan prinsip perlindungan nasabah. Dalam hal ini, apabila nasabah merasa terdapat transaksi yang mencurigakan pada rekeningnya,

\footnotetext{
${ }^{25}$ Wawancara dengan Asteria Diantika, Departemen Edukasi dan Perlindungan Konsumen, Otoritas Jasa Keuangan Kantor Regional D.I. Yogyakarta, di Yogyakarta, 5 Januari 2017

26 Wawancara dengan Abdul Rasyid, Departemen Kebijakan Sistem Pembayaran BI, di Banjarmasin, 11 Januari 2017
} 
dapat segera menghubungi bank di mana nasabah membuka rekening. Bank akan melakukan investigasi terhadap laporan yang masuk berdasarkan bukti-bukti yang ada sesuai dengan aturan/prosedur yang ada.

"Sebetulnya, pertanggungjawaban bank terhadap nasabah yang dirugikan tersebut ialah kewenangan bank yang lalai itu sendiri. Mereka semestinya sudah memiliki SOP (Standart Operational Procedure) sendiri-sendiri, tetapi tetap mengacu kepada Peraturan Bank Indonesia. Detail bagaimana pertanggungjawabannya tetap masing-masing bank itu sendiri yang memiliki kebijakan". Terang Abdul. Hal ini sesuai dengan Pasal 10 Peraturan Bank Indonesia tentang Perlindungan konsumen jasa sistem pembayaran yang berbunyi "Penyelenggara wajib bertanggung jawab kepada Konsumen atas kerugian yang timbul akibat kesalahan pengurus dan pegawai Penyelenggara".

Selanjutnya Bank Indonesia menegaskan bahwa bank wajib memiliki dan melaksanakan mekanisme penanganan pengaduan bagi konsumen, adapun mekanismenya wajib dituangkan dalam bentuk tertulis yang meliputi penerimaan pengaduan, penanganan dan penyelesaian pengaduan serta pemantauan penanganan dan penyelesaian pengaduan. ${ }^{27}$ Mekanisme penanganan pengaduan tersebut wajib diberitahukan kepada konsumen.

Penyelesaian pengaduan nasabah yaitu melalui proses mediasi perbankan melalui Bank Indonesia. Mediasi perbankan merupakan kelanjutan dari pengaduan nasabah apabila nasabah merasa tidak puas atas penanganan dan penyelesaian yang diberikan pihak bank. Dalam pelaksanaan kegiatan usaha perbankan seringkali hak-hak nasabah tidak dapat terlaksana dengan baik sehingga menimbulkan friksi antara nasabah dengan bank yang ditunjukkan dengan munculnya pengaduan nasabah.

Apabila pengaduan nasabah tidak diselesaikan dengan baik oleh bank, maka berpotensi menjadi perselisihan atau sengketa antara nasabah dengan bank yang cenderung berlarut-larut. Hal ini antara lain ditunjukkan dengan cukup banyaknya keluhan-keluhan nasabah di berbagai media. Munculnya keluhan-keluhan yang tersebar pada publik melalui berbagai media tersebut dapat menurunkan reputasi

\footnotetext{
27 Peraturan Bank Indonesia Nomor 16/1/PBI/2014 tentang Perlindungan Konsumen Jasa Sistem Pembayaran Pasal 16 ayat (1) dan ayat (2)
} 
bank di mata masyarakat dan berpotensi menurunkan kepercayaan masyarakat pada lembaga perbankan.

Untuk mengurangi publikasi negatif terhadap operasional bank dan menjamin terselenggaranya mekanisme penyelesaian pengaduan nasabah secara efektif dalam jangka waktu yang memadai, maka bank menetapkan standar minimum mekanisme penyelesaian pengaduan nasabah dalam Peraturan Bank Indonesia Nomor: 7/7/PBI/2005 tentang Penyelesaian Pengaduan Nasabah yang wajib dilaksanakan oleh seluruh Bank. Tetapi penyelesaian pengaduan nasabah oleh bank yang diatur dalam Peraturan Bank Indonesia Nomor 7/7/PBI/2005 ini tidak selalu dapat memuaskan nasabah. Ketidakpuasan tersebut dikarenakan tidak terpenuhinya tuntutan nasabah bank baik seluruhnya maupun sebagian sehingga berpotensi menimbulkan sengketa antara nasabah dengan bank.

Pihak Bank Indonesia menyatakan tidak ada perangkat hukum yang khusus untuk mengatasi kasus pembobolan dana nasabah melalui mesin ATM dengan modus card skimming, karena kejahatan yang berkaitan dengan ATM pasti menyangkut teknologi, yang mana teknologi itu terus berkembang dan dinamis. Diakui pihak Bank Indonesia memang terkadang terdapat beberapa hal yang tidak terduga diluar kemampuan Bank Indonesia. Artinya apabila Bank Indonesia membuat ketentuan khusus terkait kasus card skimming, maka justru mempersulit ruang gerak bank dalam melakukan kegiatannya. ${ }^{28}$

Dalam memberikan kepastian hukum, Bank Indonesia sudah memberikan koridor masing-masing untuk memberikan ruang gerak bagi bank dalam melakukan kegiatan usahanya. Oleh karena itu, ketentuan terkait kasus card skimming jelas tidak ada, dengan kata lain bank harus berhati-hati dan handal dalam menjalankan sistem pembayaran. Karena bisa jadi dalam beberapa waktu, metode pembobolan mesin ATM dengan card skimming sudah tidak menjadi trend lagi bagi para pelaku dalam mencuri dana simpanan nasabah.

${ }^{28}$ Wawancara dengan Abdul Rasyid, Departemen Kebijakan Sistem Pembayaran BI, di Banjarmasin, 11 Januari 2017 
Dengan perkembangan teknologi yang begitu pesat sekarang ini, nasabah dalam penggunaan kartu juga sudah dianggap barang lama. "Seperti yang kita ketahui sekarang, nasabah sudah banyak yang beralih menggunakan e-banking yang mana dapat diakses melalui smartphone dan dianggap lebih fleksibel dari pada mesin ATM itu sendiri". Tutup beliau

\section{Penutup}

Berdasarkan hasil penelitian serta pembahasan yang telah penulis sajikan pada bab-bab terdahulu, berikut disajikan kesimpulan yang merupakan jawaban terhadap permasalahan dalam penelitian ini:

Pertama, pertanggungjawaban yang dilakukan pihak bank terhadap peristiwa tindak pidana penggandaan kartu ATM yang menyebabkan kerugian hilangnya dana nasabah adalah pihak bank memberikan ganti rugi terhadap dana nasabah yang hilang tersebut dengan terlebih dahulu memastikan bahwa hilangnya dana nasabah apakah karena memang benar disebabkan oleh perbuatan tersangka penggandaan kartu ATM ataukah karena kelalaian nasabah sendiri, sehingga apabila hilangnya dana nasabah yang disebabkan oleh kelalaian nasabah sendiri, maka pihak bank tidak wajib mengembalikan kerugian yang dialami nasabah.

Kedua, perlindungan hukum terhadap korban kejahatan penggandaan kartu ATM antara lain: upaya hukum yang dapat dilakukan pihak nasabah apabila mengalami kerugian atas hilangnya dana simpanan; menurut Pasal 19 ayat (1) dan (3) Undang-Undang Perlindungan Konsumen, konsumen yang merasa dirugikan dapat menuntut secara langsung penggantian kerugian kepada produsen dan produsen harus memberi tanggapan dan/atau penyelesaian dalam jangka waktu 7 hari setelah transaksi berlangsung; dan setiap konsumen yang dirugikan dapat menggugat pelaku usaha melalui lembaga yang bertugas menyelesaikan sengketa antara konsumen dan pelaku usaha atau melalui peradilan umum ataupun penyelesaian sengketa konsumen dapat ditempuh melalui pengadilan (UUPK Pasal 45 ayat (1)) atau diluar pengadilan berdasarkan dengan pilihan sukarela para pihak yang bersengketa (UUPK Pasal 45 ayat (2)).

Upaya penindakan yang dilakukan oleh pihak bank yaitu klarifikasi pengaduan nasabah yang kehilangan dana dengan cara melakukan pengecekan 
data rekening nasabah untuk mengetahui transaksi-transaksi yang menyebabkan berkurangnya saldo rekening nasabah, lalu nasabah menyampaikan transaksi yang dirasa janggal atau tidak pernah dilakukan oleh nasabah. Selain itu juga dilakukan, pengecekan transaksi nasabah yang diduga janggal berdasarkan penyampaian nasabah, salah satunya adalah pengecekan CCTV pada mesin ATM yang penarikan uangnya tidak diakui oleh nasabah. Dari hasil pengecekan transaksi ini akan diketahui dan disimpulkan apakah transaksi tersebut sah atau transaksi janggal. Selanjutnya adalah pengembalian dana nasabah yang hilang, apabila sudah disimpulkan bahwa nasabah tidak melakukan transaksi yang tercatat pada rekening nasabah tersebut. Yang terakhir yaitu pembuatan laporan tindak pidana penggandaan kartu ATM di Kepolisian untuk dapat dilakukan penyelidikan dan penyidikan terhadap pelaku.

Sedangkan upaya pencegahan yang dilakukan oleh pihak bank yaitu pemasangan tutup pelindung keypad atau tombol angka pada mesin ATM agar tidak terlihat kode angka yang ditekan nasabah pada saat memasukkan kode PIN, pemasangan alat anti skimmer pada lubang pembaca kartu ATM dan mengoptimalkan operasional CCTV di seluruh mesin ATM, memasang himbauan kepada nasabah untuk berhati-hati dalam kegiatan transaksi di mesin ATM dan melaksanakan pengecekan secara berkala terhadap kondisi mesin dan ruang ATM, dan penerapan teknologi chip sebagai pengganti pita magnetik (magnetic stripe) pada kartu ATM yang efektif berlaku untuk seluruh nasabah bank di Indonesia.

Berdasarkan hasil penelitian di atas, penulis menyarankan: pertama, agar pemerintah menerbitkan peraturan perundang-undangan yang mewajibkan pihak bank meningkatkan keamanan mesin ATM yang dimiliki oleh bank dan menerapkan sanksi yang berat terhadap bank yang tidak melaksanakan hal tersebut sehingga dapat melindungi nasabah perbankan dari kejahatan penggandaan kartu ATM.

Kedua, agar Bank Indonesia konsisten memberlakukan aturan penggunaan teknologi chip pada kartu ATM sebagai pengganti kartu ATM dengan pita magnetik dan memberikan bantuan kepada bank untuk proses pengadaan kartu dan infrastruktur kartu ATM dengan teknologi chip serta tidak mempersulit proses 
pengembalian dana nasabah korban kejahatan penggandaan kartu ATM dan segera memperbaharui kartu ATM dengan teknologi chip untuk menjaga keamanan dana nasabah di rekening bank.

Ketiga, agar Bank Indonesia harus bekerjasama dengan bank umum perlu peningkatan penyuluhan dan edukasi kepada masyarakat luas pada umumnya dan nasabah bank pada khususnya. Bank harus bersedia menjelaskan secara terbuka proses dan cara penyelesaian persengketaan antara nasabah dengan pihak bank, khususnya pada proses penyelesaian pengaduan kerugian nasabah yang disebabkan oleh pencurian melalui card skimming pada mesin ATM. Dengan demikian bagi masyarakat awam akan dapat memperoleh suatu pembelajaran karena mereka akan mengetahui bagaimana penyelesaian yang dilakukan bank.

Keempat, agar para nasabah lebih waspada dan berhati-hati dalam melakukan transaksi di mesin ATM serta selalu melakukan penggantian nomor PIN ATM secara berkala untuk meminimalisir kemungkinan resiko menjadi korban kejahatan penggandaan kartu ATM.

\section{Daftar Pustaka}

\section{Buku}

Arthesa, Ade \& Edia Handiman, Bank \& Lembaga Keuangan Bukan Bank, PT. Indeks, Jakarta, 2006.

Hermansyah, Hukum Perbankan Nasional Indonesia, edisi ke-2. Jakarta: Kencana, 2013.

Kasmir, Dasar-Dasar Perbankan, PT. RajaGrafindo Persada, Jakarta, 2008.

Muhammad, Abdul Kadir, Hukum dan Penelitian Hukum, PT. Citra Aditya Bakti, Bandung, 2004.

Prasetya, Ronny, Pembobolan ATM; Tinjauan Hukum Perlindungan Nasabah Korban Kejahatan Perbankan, Prestasi Pustaka Publisher, Jakarta, 2010.

Sembiring, Sentosa, Hukum Perbankan, CV. Mandar Maju, Bandung, 2000.

Serfianto, R. et. al, Untung dengan Kartu Kredit, Kartu ATM-Debit, dan uang Elektronik, Visimedia, Jakarta, 2012.

Sihombing, Jonker, Penjaminan Simpanan Nasabah Perbankan, PT. Alumni, Bandung, 2010.

Soekanto, Soerjono, Pengantar Penelitian Hukum, UI-Press, Jakarta, 1982. 


\section{Jurnal}

Dyah Worosari. Tinjauan Yuridis Terhadap Keamanan Penggunaan Kartu ATM/Debet di PT Bank Negara Indonesia, Tbk (Persero). Skripsi: Universitas Indonesia, tidak diterbitkan, 2012.

\section{Wawancara}

Wawancara dengan Pambudi, IT Infrastructure, Bank Mandiri Lambung Mangkurat cabang Banjarmasin, di Banjarmasin

Wawancara dengan Asteria Diantika, Departemen Edukasi dan Perlindungan Konsumen, Otoritas Jasa Keuangan Kantor Regional D.I. Yogyakarta, di Yogyakarta

Wawancara dengan Abdul Rasyid, Departemen Kebijakan Sistem Pembayaran BI, di Banjarmasin 